\title{
Effectiveness of Toileting Training Mediated with Animated Videos Against to Independence Level of Toileting on Pre- School Children
}

\author{
Nunung Ernawati, Kartika Permata \\ Nursing Program Of Health Politechnic RS Dr. Soepraoen, Malang, East Java, Indonesia \\ Corresponding author: nunungerna@gmail.com
}

\begin{abstract}
Background: The one of development tasks for preschooler that must be passed is toileting activity. Toileting learning need should start at toodler phase, but many children still enuresis experience in the classroom, all students could not do proper toileting, including not knowing how to go to the toilet, not being able to open the pants and not being able to flush the elimination urine and defecatie in Kindergarden-class A of Malang City. Inability to control of elimination urine that cause of pre schooler are less independece for toileting activity.
\end{abstract}

Purpose: This study aimed to find out the effect of toilet training mediated with animated videos againts to independence level of toileting on pre schooler children in kindergartenclass A of Malang City.

Methods: This type of research was analytic observation with a pre-experimental approach. The total population was 38 children, the number of samples 38 children was taken using the total sampling technique. The variable measured is the level of independence of toileting. The data was processed then analyzed using the Wilcoxon test with $\alpha<0.05$.

Results: Based on the results of the study, the level of independence before toileting learning was done $21 \%$ independently and $79 \%$ not independently. The level of independence after toileting learning is $100 \%$ done independently.Wilcoxon test was analyzed, the level of independence was obtained with a p-value of 0,000 which means that $\mathrm{p}$-value $<\alpha$ so that $\mathrm{H} 0$ is rejected, which means there is an influence of the learning activity of animated videos on the level of independence of toileting.

Conclusion:Based on the results of the study, to improve children's independence, in terms of toileting, can be done early and in the future learning, animated video media can be used as an alternative as a learning media for pre-schooler.

Keywords: Animated Videos, Toileting Independence, Pre-Schooler

Received July, 29, 2019; Revised August 30, 2019; Accepted September 22, 2019

How to Cite: Ernawati, N., \& Permata, K. (2019). Effectiveness of Toileting Training Mediated with Animated Videos Against to Independence Level of Toileting on Pre-School Children. Journal Of Nursing Practice, 3(1), 102-108. https://doi.org/10.30994/jnp.v3i1.71 


\section{BACKGROUND}

Children are individuals who are in a range of developmental changes starting from infants to teenagers. One of development tasks for children aged 4-5 years old (preschooler) that should be passed is toileting activities. Toileting is a teaching process as well as efforts to train the child's ability to control urination (BAK) and defecation (BAB) is properly and regularly (Hidayat, 2008). Toileting learning needs should have been started since the children aged 1-3 years, but in kindergarten-class A are still many children aged 4-5 years who are still experiencing enuresis in the classroom, can not open his own pants, can not control the urge to urinate. Inability to control the urge to urinate cause children less independent in toileting needs.

The prevalence of enuresis in the world ranged between $11.4 \%-45 \%$. Studies in the USA show of 112 children aged 3-10 years, $45 \%$ have daytime wetting or daytime wetting (Hodges et al., 2014). Qena, Egypt, 1,065 (11.4\%) school-age children experience enuresis (Ismail et al., 2013). In Indonesia the estimated number of infants up to $30 \%$ of the million population of Indonesia in 2011. According to National Household Health Survey in 2012, estimated the number of toddlers who are hard to control bowel movements and urination (enuresis) reach 75 million preschool-age children.

According to the preliminary study conducted by researchers at the date of October 1, 2018, the information obtained from the Principal of Kindergarten that 20 children in kindergarten-class A of Malang City are already independent in toileting, while 18 children are still not independently perform toileting. Among 5 children do not know how to toilet, 5 children can not open the pants, and 8 children who can not cleanse or flush after urinating or bowel movements. Teachers already done verbally teaching, this course is not enough, because children still do not understand what is conveyed by the teacher. Toileting failure caused by premature toileting be likely to cause urinary tract infection (UTI) (Natalia, 2006). In addition, toileting failure can cause a child less independent, have a selfish attitude, stubborn, greedy, tend to be careless, and arbitrarily in performing daily activities (Hidayat, 2008).

Efforts to overcome the problem of toileting in children aged 4-5 years with an interesting learning through the media, for example with animated video, posters, roleplay, and storytelling (Maria Sicily, 2010). One of the media that will be examined are animated video, selected video as a learning media about toileting can be used both within the children as well as in the environment of adults, in addition to the video animations can be a special attraction for children to consider the content of that learning.

\section{OBJECTIVE}

This study aimed to investigate the effect of exercise toileting through animated videos on the level of toileting independence of pre-school children in Kindergarten-class A of Malang city.

\section{METHODS}

The research design was an observational analytic with pre-experiment approach. The study population was the students of kindergarten-class A of Malang city numbered 38 children. Sampling used total sampling so that the sample was 38 children of kindergarten-class A of Malang city. The variables studied were toileting independence through the intervention of toileting training through the media of animated video. The study was conducted in kindergarten-class A of Malang city on December 2018. Data 


\section{Journal Of Nursing Practice}

http://thejnp.org

ISSN: 2614-3488 (print); 2614-3496 (online)

Vol.3 No.1. October 2019. Page.102-108

were collected before and after the intervention of toileting training through the media of animated videos, instructional videos provided $3 \mathrm{x}$ in one week was conducted for 2 weeks in the school with a duration of 2 minutes on Mondays, Wednesdays and Friday. After data collection will be conducted editing stages of data processing, coding, tabulating then analysis Wilcoxon test with $\alpha=0.05$. This study was conducted according to the principles of research ethics was anonimyty, confidentiality, inform consent, benefit and potential risk of research.

The participants were assured that their engagement was voluntary, and that anonymity, privacy, and confidentiality of the data were guaranteed. Furthermore, they were informed about the purpose and the method of the study before signing a written informed consent. The questionnaires were distributed to eligible participants at the kindergarten, and respondents were asked to complete and return them in the same time.

\section{RESULTS}

This research was conducted in Kindergarten-calss A at Lowokwaru District of Malang City. Kindergarten of Malang city used bi-lingual learning system with total of 75 students divided into kindergarten A 40 children and kindergarten B 35 children, while the total number of teachers and staff there are 10 people. Learning is carried out every Monday until Friday at 07.00-10.00 AM.

Based on the results general data characteristics as follows;

\section{Diagram 1}

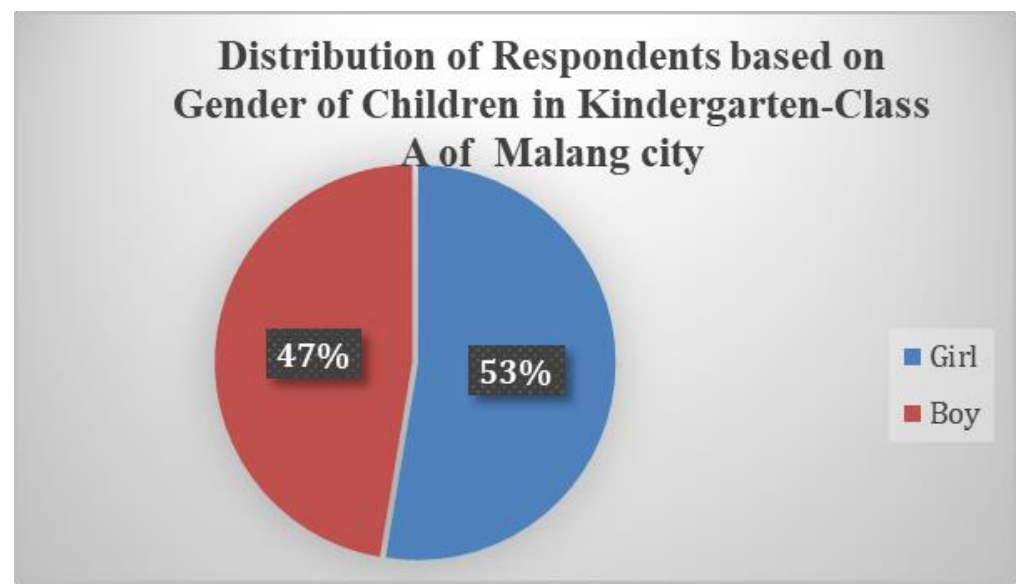

Based on the above diagram shown that the majority gender of children in kindergarten in class A of Malang City were girls (53\%). 


\section{Journal Of Nursing Practice}

http://thejnp.org

\section{Diagram 2}

\section{Distribution of Respondents based on Educationa \\ Level of Parents in Kindergarten-Class A of \\ Malang city}

ES= Elementary School, JHS=Junior High School, SHS=Senior High School

Based on the diagram above shown that the majority of educational level of parents was Senior High School (87\%).

\section{Diagram 3}

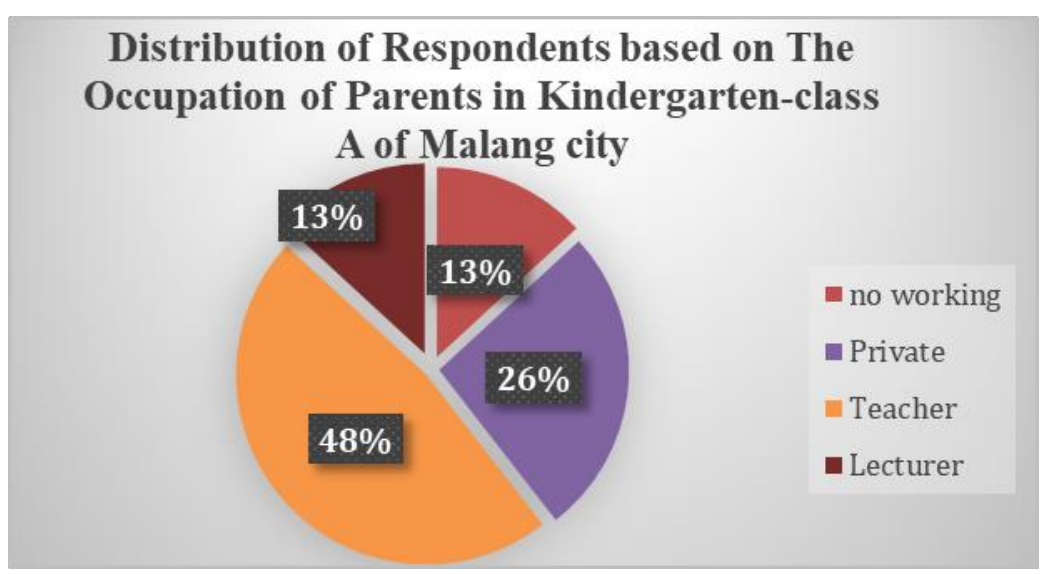

Based on the diagram above, shows that the occupation of parents in Kindergarten of Palm Kids mostly teachers $(51 \%)$

\section{Diagram 4}

The Independence of Toileting Before Toileting

Training Mediated with Animated Video

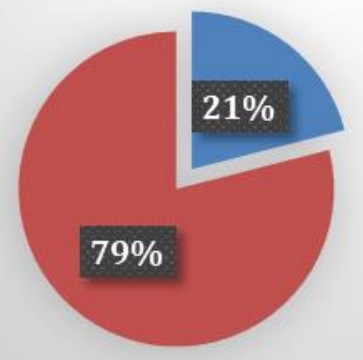

$$
\begin{aligned}
& \text { Independent } \\
& \text { Not independent }
\end{aligned}
$$

Based on the diagram above shown that the independence of toileting before toileting practice using video was largely self-sufficient (79\%) 


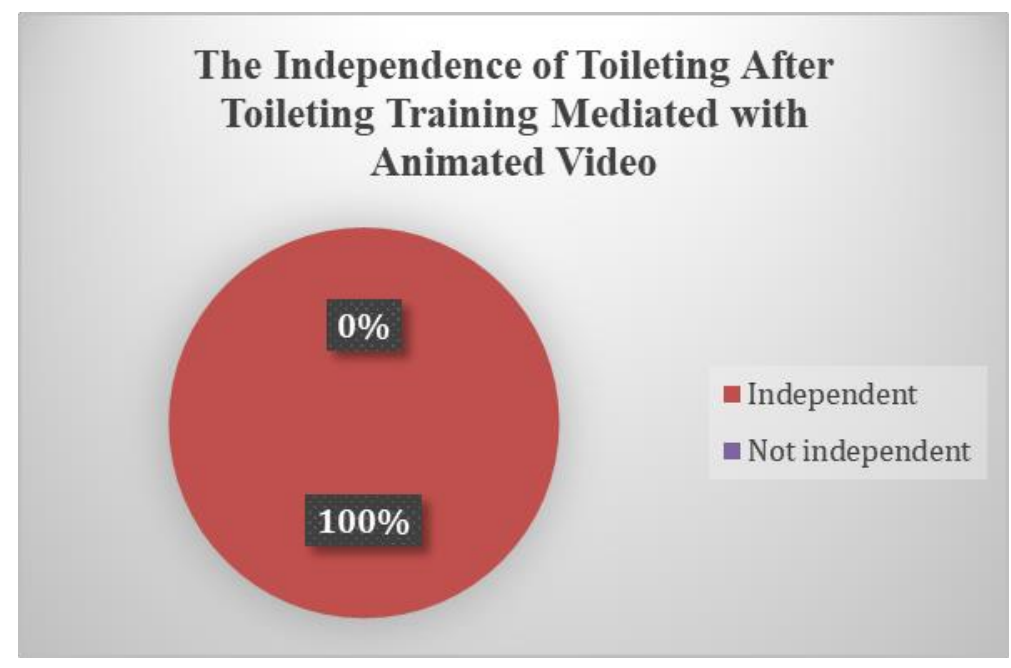

Based on diagram above shown that the independence of toileting after toileting drills conducted entirely $(100 \%)$ in the independent category.

The Analysis Results Independence Level Difference on Pre Test and Post Test on Kindergarten-class A of Malang City

\begin{tabular}{llcc}
\hline & $\mathbf{N}$ & $\begin{array}{c}\text { Median } \\
\text { (Minimum-Maximum) }\end{array}$ & $p$ \\
\hline Pre Test Independence Children & 38 & $23(19-33)$ & 0,000 \\
\hline Post Test Independence Children & 38 & $34(30-44)$ & \\
\hline $\begin{array}{l}\text { (Source: Primary Data Research, } \\
\text { 2019) }\end{array}$ & &
\end{tabular}

Based on the above table post test results obtained throughout the child's level of independence kindergarten-class A of Malang City standalone total of 38 children $(100 \%)$. The result of the level of independence Wilcoxon $p$ value of 0.000 and the $Z$ value of -5.390 so that $\mathrm{H} 0$ is rejected, which there is an influence of the learning activity of animated videos on the level of independence of toileting.

\section{DISCUSSION}

The measurement results on the child's independence level on pre-test shown a level of independence largely independently a number of 30 children (79\%) and a small self-contained a number of 8 children $(21 \%)$.

The results of the measurement of the degree of independence post-test showed all respondents independently a number of 38 children (100\%), so this suggests that the measurement of the level of independence to experience the difference. So it could be concluded that the intervention Video Animation can increase the degree of independence of toileting in children.

The measurement results between pre-test and post-test level of independence, showing where the Wilcoxon test results between pre-test and post-test was obtained $p$ value of 0.000 and $-5.390 \mathrm{Z}$ of these results indicates that the $\mathrm{p}$ value $<\alpha$ so $\mathrm{H}_{0}$ is 


\section{Journal Of Nursing Practice}

http://thejnp.org

ISSN: 2614-3488 (print); 2614-3496 (online)

Vol.3 No.1. October 2019. Page.102-108

rejected, it indicates that the measurement results increased level of independence before and after intervention. So it could be concluded that the intervention animated video can increase the level of independence in children 4-5 years old.

In this study showed respondents in the age range of 4-5 years old, Soegondo (2011) explains that the age is one factor that can affect the level of the child's independence. Mubarok (2007) and Notoadmojo (2014) suggests that age is a factor that can affect the level of independence. That is

with increasing age there will be changes on the physical and psychological (mental) someone who will be able to affect the level of independence. Research conducted by Maria Sicily (2010) suggested that the age of one can affect the level of independence, because the age-old enough to increase one's mindset.

This study uses a given media video animation as much as $12 \mathrm{x}$ in 2 weeks this greatly affects the independence of toileting children for use entrancing impressions in a simple and practical things easier to follow by children. Video animation provided directly on the applicative respondents.

According Wong (2008) that the video animation is a media which is suitable for children aged 4-5 years with a view transform and improve the level of independence of toileting children and to facilitate the achievement of health goals, which effectively motivate change in a structured, through a supportive relationship between the participants and coaches, In line with the research of Difran (2015) which states that the coaching support can influence the respondents in the management of its independence.

\section{CONCLUSION}

Based on the research that has been conducted, it can concluded that: The level of the child's independence before being given an animated video obtained largely dependent categorized 30 respondents $(79 \%)$ and a small self-contained a number of 8 respondents $(21 \%)$.

The independence level of children after toileting training given through the media of animated video showing a $100 \%$ self-sufficient. Because the results of data analysis by Wilcoxon Test Macth Pair obtained p value of $0.000>\alpha 0,05$ hence $\mathrm{H}_{0}$ was rejected that meant there is an influence of the learning activity of animated videos on the level of independence of toileting on children of kindergarten-class A of Malang city.

\section{ACKNOWLEDGMENTS:}

1. Letnan Kolonel CKM Arief Efendi, S.M.Ph.,SH., S.Kep.Ners., MM., M.Kes. as Directory of Health Politechnic RS Dr. Soepraoen Malang, Thanks you for the opportunity given to us as lecturers so that we can carry out the tasks of TRI Dharma PT in particular this research.

2. Headmaster and Kindergarten teacher, thanks you for your permission and support so this research can be carried out smoothly

3. All respondents and respondens parents, thanks you for your participating in this research.

\section{CONFLICTS OF INTEREST}

Many children still enuresis experience in the classroom, all students could not do proper toileting, including not knowing how to go to the toilet, not being able to open the pants 


\section{Journal Of Nursing Practice}

http://thejnp.org

ISSN: 2614-3488 (print); 2614-3496 (online)

Vol.3 No.1. October 2019. Page.102-108

and not being able to flush the elimination urine and defecatie in Kindergarden-class A of Malang City.

\section{REFERENCES}

Ali, and Asrori (2002), Factors Affecting Learning independence. http: // alan-lahallo .com / 2011/06 / factors-yangmempengaruhi.html. Accessed on October 29, 2018

Aziz, RU (2006), Do not Let Our Children Grow with Bad Habit, cet. 1. Solo: Triad.

Hidayat, A. Aziz Alimul (2008), Introduction to Nursing Children 1 Jakarta: Salemba Medika.

Medika. , (2009), Introduction to Nursing Children. Jakarta: Salemba

Kabang, MS (2010). Influence Toilet Training by Using the Media Image Attitude Independence Against Children aged 4-5 years in kindergarten builder Negri South Pontianak.

Notoatmodjo, S. (2010), Health Research Methodology. Jakarta: Rineka Reserved.

Nursalam (2013) Nursing Research Methodology: A Practical Approach Edition 4. Jakarta: Salemba Medika.

Natalia, S. 2006. "Effect" Toilet Training "against UTI Recurrent Events in Girls Ages 1-5 years". Thesis S2 Graduate Program in Biomedical Science and a Master of Specialist Education Program 1 Child Health Diponegoro University, Semarang.

Sugiyono. (2013). Educational Research Methods. Bandung: Alfabeta.

Wong. Donna L. 2008, Textbook of Pediatric Nursing. Jakarta: EGC 